\title{
Intramuscular methergine versus per-rectal misoprostol for prevention of atonic post-partum haemorrhage
}

\section{Rajeshwari Singangutti*}

\begin{abstract}
Department of Obstetrics and Gynecology, Chalmeda Anand Rao Institute of Medical Sciences, Karimnagar,
\end{abstract} Telangana, India

Received: 18 January 2018

Accepted: 28 February 2018

\section{*Correspondence:}

Dr. Rajeshwari Singangutti,

E-mail: rajeshwari1983@gmail.com

Copyright: () the author(s), publisher and licensee Medip Academy. This is an open-access article distributed under the terms of the Creative Commons Attribution Non-Commercial License, which permits unrestricted non-commercial use, distribution, and reproduction in any medium, provided the original work is properly cited.

\section{ABSTRACT}

Background: Postpartum haemorrhage (PPH), is a major hazard of maternal death which is accounting for $30 \%$ of deliveries with a $1 \%$ mortality rate globally. Present study was designed to compare the efficacy of per rectal misoprostol and intramuscular methergine in the management of $3^{\text {rd }}$ stage labour for prevention of postpartum haemorrhage.

Methods: A total four hundred cases with low risk term pregnancy admitted and attending department of obstetrics and gynecology were considered and were divided in 2 groups such as group 1 consists of 200 patients administered with misoprostol $600 \mu \mathrm{g}$ after delivery and group 2 consists 200 patients administered with methyl ergometrine $0.2 \mathrm{mg}$ (intramuscular) after delivery.

Results: Methyl ergometrine group had a significant reduction in duration of third stage $(\mathrm{p}<0.05)$ and blood loss $(\mathrm{p}<0.05)$ when compared to misoprostol group. Need for additional Oxytocics was also more in misoprostol group (8\%) as compared to methyl ergometrine group (4\%). In group 1 average blood loss was found to be $241.3 \mathrm{ml}$, whereas in group 2 it was $179.3 \mathrm{ml}$. Average $\mathrm{Hb}$ levels were significantly reduced in group 2 when compared to group 1 patients. Incidence of side effects like nausea, vomiting is more in methergine group than misoprostol group.

Conclusions: Intramuscular methergine results in lower blood loss, reduction in duration of third stage of labour, significantly reduction in hemoglobin level after delivery but is associated with more side effects while per rectal misoprostol is less effective but safe with lesser side effects.

Keywords: Methylergometrine, Misoprostol, Postpartum haemorrhage, Third stage labour

\section{INTRODUCTION}

Third stage labour is the most complicated part of the mother, which requires necessary attention. The most usual happen condition in this stage is postpartum haemorrhage defined as blood loss $>500 \mathrm{ml}$ in the first 24hours of post-delivery. ${ }^{1}$ It is an important cause of maternal morbidity and mortality. ${ }^{2-4}$ The world health organization (WHO) reports that over 20 million morbidities results every year due to post-partum haemorrhage. ${ }^{5}$
Preventive measures like early cord cutting, supplementation of Oxytocics and cord traction may decrease the probability rate of postpartum haemorrhage. ${ }^{6-8}$ Conventional treatment for prophylaxis against postpartum haemorrhage include methyl ergometrine, oxytocin and 15 methyl PGF2 $\alpha$. Usage of oxytocic agents shown to decrease incidence of postpartum haemorrhage by $40 \%$ The use of uterotonic agent may reduce blood loss but often associated with nausea, vomiting, myocardial infarction, intracerebral haemorrhage and increased BP. ${ }^{9}$ Misoprostol an effective 
uterotonic agent which binds selectively to EP2 or EP3 prostonoid receptor administering orally or rectal route to prevent postpartum hemorrhage and helpful in the management of third stage labour. ${ }^{10}$ Methergine is a conventional oxytocic used extensively but is associated with unpleasant side effects like hypertension. ${ }^{11}$

With the above facts the present study attempted to compare intramuscular methergine and perrectal misoprostol in the management of third stage labour for prevention of post-partum haemorrhage.

\section{METHODS}

The present study was conducted in department of Obstetrics and Gynecology, Chalmeda Anand Rao Institute of Medical Sciences, Karimnagar during March 2016 to September 2017. A total 400 cases attended and admitted in the department and fulfilling the selection criteria were considered. Patients between 20-30 years age group, gravida ranging from $1^{\text {st }}-4^{\text {th }}$ and between 36 40 weeks of gestation were included. Patients with pregnancy induced hypertension, cardiovascular diseases, renal disorders, antepartum haemorrhage, bronchial asthma, previous caesarean and multiple pregnancies were excluded from the study. Informed consent was obtained from all the patients. All the participants underwent through general and systemic examination like per vaginal, per abdominal, cardiovascular and respiratory examinations. Based on the drug administered, the patients were divided into two groups such as group 1 with misoprostol $600 \mu \mathrm{g}$ through perrectally immediately after birth of baby and group 2 with intramuscular Inj. methergine $0.2 \mathrm{mg}$ at the time of delivery to anterior shoulder.

The blood loss during the third stage of labour and the immediate postpartum period (1 hour after delivery) was calculated by placing plastic sheet under the women's buttocks and on the floor and by keeping a sterile kidney tray at the vulva. After the delivery of fetus, amount of blood loss is estimated by totaling up the blood in kidney tray, secondary blood spillage on plastic sheets and collected blood and blood clots and volume measured by a measuring jar. If intravenous oxytocin was used during the second stage of labour, it was stopped immediately after delivery. Length of third stage of labour, and side effects including nausea, vomiting, diarrhoea, shivering, hypertension and retained placenta were recorded. Statistical analysis of the 2 groups was done by Chisquare test and t-test (normality test).

\section{RESULTS}

A total 400 cases with low risk term pregnancy admitted and attending department were considered. Group 1 consists of 200 patients administered with misoprostol $600 \mu \mathrm{g}$ after delivery and group 2 consists 200 patients administered with methyl ergometrine $0.2 \mathrm{mg}$ (intramuscular) after delivery.

Table 1: Age wise distribution of cases.

\begin{tabular}{|lllll|}
\hline $\begin{array}{l}\text { Age } \\
\text { (in years) }\end{array}$ & No. & Percent & No. & Percent \\
\hline $20-22$ & 54 & 27 & 67 & 33.5 \\
\hline $23-26$ & 88 & 44 & 105 & 52.5 \\
\hline $27-30$ & 58 & 29 & 28 & 14 \\
\hline
\end{tabular}

In misoprostol group $56 \%$ of cases were multigravidas and $49 \%$ were primigravida but in methergine group $40 \%$ were multigravidas and $60 \%$ were primi gravidas. In misoprostol (52\%) and methergine groups (49\%) majority of patients were between 39-40 weeks of gestation. Mean period of gestation in misoprostol group was 38.5 weeks and in methergine it was 38.4 weeks. In misoprostol group, average duration of 3rd stage of labour was found to be 8.98 minutes whereas in methergine group it was found 6.02 minutes $(\mathrm{p}<0.05)$.

Table 2: Volume of blood loss during third stage of labour.

\begin{tabular}{|lllll|}
\hline $\begin{array}{l}\text { Blood } \\
\text { volume }(\mathrm{ml})\end{array}$ & No. & Percent & No. & Percent \\
\hline$<100$ & 18 & 9 & 67 & 33.5 \\
\hline $101-200$ & 67 & 33.5 & 108 & 54 \\
\hline $201-300$ & 73 & 36.5 & 10 & 5 \\
\hline $301-400$ & 22 & 11 & 7 & 3.5 \\
\hline $401-500$ & 5 & 2.5 & 3 & 1.5 \\
\hline $501-600$ & 15 & 7.5 & 5 & 2.5 \\
\hline & $\mathrm{P}<0.05$ & & & \\
\hline
\end{tabular}

Table 3: Effect of SBP and DBP in both group patients.

\begin{tabular}{|c|c|c|c|c|c|c|c|c|}
\hline & \multicolumn{4}{|c|}{ Systolic blood pressure } & \multicolumn{4}{|c|}{ Diastolic blood pressure } \\
\hline & \multicolumn{2}{|c|}{ Group 1} & \multicolumn{2}{|c|}{ Group 2} & \multicolumn{2}{|c|}{ Group 1} & \multicolumn{2}{|c|}{ Group 2} \\
\hline & No & Percent & No & Percent & No & Percent & No & Percent \\
\hline Rise or insignificance change & 158 & 79 & 134 & 67.5 & 171 & 85.5 & 138 & 69 \\
\hline Rise of $5-10 \mathrm{~mm} \mathrm{Hg}$ & 5 & 2.5 & 32 & 16 & 4 & 2 & 38 & 19 \\
\hline Fall of $5-10 \mathrm{~mm} \mathrm{Hg}$ & 37 & 18.5 & 34 & 17 & 25 & 12.5 & 24 & 12 \\
\hline
\end{tabular}


In group 1, additional oxytocin (10 IU) in intravenous drip was required in $8 \%$ patients and average blood loss was found to be $241.3 \mathrm{ml}$. Whereas in group 2, additional oxytocin was needed in $4 \%$ of patients and average blood loss was found to be $179.3 \mathrm{ml}$. $11 \%$ of cases had blood transfusion in group 1 whereas it was $8 \%$ in group 2 . Average $\mathrm{Hb}$ levels were significantly reduced in group 2 when compared to group 1 patients.

Table 4: Side effects of drugs in both group patients.

\begin{tabular}{|lllll|}
\hline \multirow{2}{*}{ Side effects } & Group 1 & Group 2 \\
\hline Vomiting & 5 & 2.5 & 18 & 9 \\
\hline Pyrexia & 2 & 1 & 1 & 0.5 \\
\hline Nausea & 6 & 3 & 21 & 10.5 \\
\hline Diarrhea & - & & - & \\
\hline Shivering & 3 & 1.5 & 6 & 3 \\
\hline Abdominal cramps & - & & - & \\
\hline
\end{tabular}

\section{DISCUSSION}

The third stage labour is potentially most complicated part of the mother. The present study aimed to compare the efficacy of intramuscular methergine $(0.2 \mathrm{mg})$ and per rectal misoprostol $(600 \mu \mathrm{g})$ in the management of $3 \mathrm{rd}$ stage of labour. In present study majority patients were between age group 23-26 years which is similar to study by Vrunda Joshi et al (23 years) and Frederic et al (29.8 Years) (Table 1). ${ }^{12}$ Majority patients were multigravidas in group $1(56 \%)$ whereas in group 2 majority are primigravida i.e. $60 \%$ which is correlating with the findings of Joshi $\mathrm{V}$ et al. ${ }^{12}$

The raise in systolic blood pressure was not statistically significant between two groups before and after delivery. Therefore, intramuscular methergine is exclusively associated with increase in systolic blood pressure. In a study by Frederic et al, it was found that one hour after birth of baby there was no difference in mean systolic blood pressure or the mean diastolic blood pressure in methyl ergometrine or misoprostol group respectively. In view of changes in diastolic blood pressure following delivery, in methergine group there is considerable rise in diastolic blood pressure with $\mathrm{p}<0.05$ which is significant as compared to misoprostol group. Rise in BP was more in methyl ergometrine group as compared to misoprostol group, rise in systolic blood pressure was seen in $16 \%$ of cases and rise in diastolic blood pressure in $38 \%$ of cases. In misoprostol group there was increase in systolic blood pressure in only $2.5 \%$ and increase in diastolic blood pressure in only $2 \%$ of cases.

In the study by Frederic et al, the mean blood loss was same in both misoprostol and methyl ergometrine group. In the study by Joshi $\mathrm{V}$ et al when methyl ergometrine was compared to misoprostol, there was $200.87 \mathrm{ml}$ mean blood loss in methyl ergometrine group while lesser amount of blood loss i.e. $195 \mathrm{ml}$ mean blood loss was seen in misoprostol group. ${ }^{12}$ The result of our study shows that third stage blood loss and hemoglobin deficit were not significantly different in control and study group. This is in accordance with the results of other studies. ${ }^{12,13}$ Study by Mansouri HA et al compared rectal vs oral misoprostol 600ug in active management of 3rd stage labour, found that mean blood loss was higher in oral misoprostol than rectal admintered. ${ }^{14}$

In the present study incidence of side effects like nausea (3\%) and vomiting (2.5\%) were less in misoprostol group as compared to methyl ergometrine group. In methyl ergometrine group incidence of nausea was $10.5 \%$ and vomiting $9 \%$. Shivering was more in methyl ergometrine group i.e. $3 \%$ as compared to $1.5 \%$ in misoprostol group. Pyrexia was found in misoprostol group which was $1 \%$ and $0.5 \%$ in methergine group. In a similar study by Frederic et al., pyrexia was observed in $34 \%$ cases in misoprostol group compared to $3 \%$ in methyl ergometrine group. Shivering occurred in $42 \%$ cases of misoprostol group compared to $8.5 \%$ in methyl ergometrine group. There was no difference in two group in the occurrence of nausea, vomiting, diarrhoea, hot flushes, headache or vertigo. In a similar study by Vrunda Joshi V et al, shivering, diarrhoea and fever were common side effects in misoprostol group. Nausea, vomiting, increase in BP were common in methyl ergometrine group. ${ }^{12}$ Study by Mansouri HA, Alsahly N, found that shivering and pyrexia were occurred more in oral misoprostol group and concluded that rectal misoprostol is effective in the management of $3^{\text {rd }}$ stage labour. ${ }^{14}$

\section{CONCLUSION}

Per rectal misoprostol is safe with lesser side effects and can be used even in hypertensive patients for preventing $\mathrm{PPH}$ but is relatively less effective in preventing blood loss, resulting in higher fall of $\mathrm{Hb}$ level with greater number of cases requiring blood transfusion and required additional oxytocics with a higher frequency. Incidence of retained placenta was less as compared to methyl ergometrine group. Hence a cafeteria approach is required in usage of these drugs in general in reducing post-partum haemorrhage and thereby maternal morbidity and mortality.

\section{Funding: No funding sources \\ Conflict of interest: None declared \\ Ethical approval: The study was approved by the Institutional Ethics Committee}

\section{REFERENCES}

1. Prendiville W, Elborn D. Care during the third stage of labor. In: Chalmers I, Enkin M, Keirse MJNC, editors. Effective care in pregnancy and childbirth, vol I. Oxford: Oxford University Press; 1989:11451169.

2. Ratnam SS, Viegas OAC, Singh K. Magnitude and causes of maternal mortality as a basis for its 
prevention. In: Kassel E, Awan AK, editors. Maternal and child care in developing countries. Zurich, Switzerland: Ott Publishers; 1989:80-90.

3. Turmen T. Safe motherhood: a global problem. In: Report from a symposium on the prevention and management of anemia in pregnancy and postpartum hemorrhage. World Health Organization. Zurich, 1996;1-13.

4. Gaud HT, Connors KA. Misoprostol dehydration kinetics in aqueous solution in the presence of hydroxypropylmethylcellulose. J Pharm Sci. 1992;81:145-8.

5. Cook CM, Spurrett MM, Murray, H. A randomized clinical trial comparing oral misoprostol with synthetic oxytocin or syntometrine in the third stage of labor. Aust NZJ Obstet Gynaecol. 1999;39(4):414-9.

6. De Groot AN. Prevention of postpartum hemorrhage. Bailliere's Clin Obstet Gynecol. 1995;9(3):619-31.

7. Prendiville WJ. The prevention of postpartum hemorrhage-optimizing routine management of the third stage of labor. Eur J Obstet Gynecol Reprod Biol. 1996;69:19-24.

8. Rogers J, Wood J, McCandlish R, Ayers S, Truesdale A, Elbourne D. Active versus expectant management of third stage of labor: the Hinching brooke randomized trial. Lancet. 1998;351(9104):693-9.

9. Supe PA, Kore SJ, Nandanwar YS. A comparative study of efficacy of misoprostol with methyl ergometrine and carboprost in active management of third stage of labour. Int J Reprod Contracept Obstet Gynecol. 2016 May;5(5):1525-31.

10. Senior J, Marshall K, Sangha R, Clayton JK. In vitro characterization of prostanoid receptors on human myometrium at term pregnancy. $\mathrm{Br} \mathrm{J}$ Pharmacol. 1993;108:501-6.

11. Kumar JS, Kumar BB, Samal S. Is there any difference between methylergometrine and syntometrine in the active management of third stage labour? Indian J Mat Child Health. 2011;13(3).

12. Joshi V, Sapre S, Jaiswal N, Olyai R. Comparative study between per rectal misoprostol and I.M. methergin for prophylaxis of PPH. Obstet Gynecol. 2006;9(3):160-2.

13. Anderson T. Prostaglandins for prevention of postpartum hemorrhage. Prect Midwife. 2005;8:43-5.

14. Mansouri HA, Alsahly N. Rectal versus oral misoprostol for active management of third stage of labor: a randomized controlled trial. Arch Gynecol Obstet. 2011;283(5):935-9.

Cite this article as: Singangutti R. Intramuscular methergine versus perrectal misoprostol for prevention of atonic post-partum haemorrhage. Int $\mathrm{J}$ Reprod Contracept Obstet Gynecol 2018;7:1490-3. 